\title{
Financial development and economic performance
}

\section{Doctoral Thesis}

Author(s):

Kappel, Vivien

Publication date:

2009

Permanent link:

https://doi.org/10.3929/ethz-a-005832695

Rights / license:

In Copyright - Non-Commercial Use Permitted 


\title{
Financial Development and Economic Performance
}

\author{
A dissertation submitted to \\ ETH ZURICH
}

for the degree of

Doctor of Sciences

\author{
presented by \\ VIVIEN KAPPEL \\ lic. oec. publ., University of Zurich \\ 14.10.1980 \\ citizen of Zurich \\ accepted on the recommendation of \\ Prof. Dr. Lucas Bretschger \\ Prof. em. Dr. Hans Geiger
}

2009 


\section{Thesis Summary}

The relationship between financial and real economic development has been intensively discussed in the economic literature. As a large number of theoretical models and empirical studies show, the close relationship between the financial sector and real economic development becomes particularly manifest in times of global financial and, often as a consequence, economic crises.

In times of well-functioning markets, a healthy financial sector provides the economy with important functions and services through various channels. The consolidation of savings and investment opportunities, the careful selection of profitable investments and accordingly the efficient allocation of resources allow other sectors to finance investments and innovations, and thus to spur technological progress and promote flourishing economic development. Conversely, the close relation between the financial system and the real economy is also associated with risks, when - due to market failures - the financial sector is no longer capable of providing the economy with the required funds and services.

This thesis addresses selected aspects of the relationship between financial development and economic performance.

The introductory chapter gives a historical overview of the role of financial systems in economic thinking.

The second chapter deals with the topic of asymmetric information in financial markets and its consequences for innovation and economic growth. An endogenous growth model is used to examine how information asymmetries between two agents that jointly contribute to the development of innovative capital goods affect innovation and the rate of economic growth. The asymmetric distribution of information raises a double-sided 
moral hazard problem, which in turn reduces the work effort of both agents. Numerical simulations highlight that the decreased work efforts lower the success probability of innovations by approximately $25 \%$, which substantially constrains innovative activity and economic growth.

The third chapter examines the effects of financial development on income inequality and poverty, using several different indicators of financial development, and taking into account the particular differences between developing and developed countries by splitting the sample into different sub-samples. The results imply that financial development substantially helps to reduce income inequality and poverty. In particular, the findings not only highlight the role of sophisticated loan markets, but also emphasize the importance of well-developed stock markets.

Chapter 4 analyzes the determinants of financial development, in particular the competitiveness of banking industries. The results suggest that a relatively large stock market enhances the competitiveness of the banking sector. An efficient cost management does not only increase the performance of the particular bank in the short run, but also promotes the competitiveness of the entire industry. It is shown that high market concentration has a negative impact on the competitiveness of banking industries.

Finally, the last chapter investigates whether the disclosure of human rights abuses by firms affects their financial performance. An international sample covering four different countries is used to analyze the returns of the firms at the time when the abuse becomes public. The results for US and UK firms suggest that investors punish unsocial corporate behavior via the stock market with clearly negative, abnormal returns. However, there is no such evidence for Germany and Switzerland. 


\section{Kurzfassung}

Der Zusammenhang zwischen Finanz- und Realentwicklung wird in der ökonomischen Literatur intensiv diskutiert. Nebst einer langen Reihe theoretischer Modelle und empirischer Studien manifestiert sich die enge Beziehung zwischen dem Finanzsektor und der realwirtschaftlichen Entwicklung auch besonders deutlich in Zeiten globaler Finanzund damit oft einhergehender Wirtschaftskrisen.

In Zeiten funktionierender Märkte versorgt ein gesunder Finanzsektor die Gesamtwirtschaft über zahlreiche Kanäle mit wichtigen Funktionen und Dienstleistungen. Die Zusammenführung von Ersparnissen und Investitionsmöglichkeiten, die sorgfältige Auswahl profitabler Anlagen und somit die Sicherstellung einer effizienten Ressourcenallokation ermöglichen anderen Sektoren, Investitionen und Innovationen zu finanzieren und so technischen Fortschritt und das Blühen der Gesamtwirtschaft voranzutreiben. Umgekehrt birgt die enge Beziehung zwischen dem Finanzystem und der Realwirtschaft auch Risiken, wenn Märkte versagen und der Finanzsektor nicht mehr länger in der Lage ist, die Ökonomie mit den benötigten Funktionen und Mitteln zu versorgen.

Die vorliegende Arbeit befasst sich im Rahmen von vier Artikeln mit verschiedenen Aspekten des Zusammenspiels von Finanz- und Realentwicklung.

Das einleitende Kapitel zeigt auf, wie sich die Rolle des Finanzsystems im ökonomischen Denken historisch entwickelt hat.

Das zweite Kapitel befasst sich mit der Thematik der Informationsasymmetrie in Finanzmärkten und deren Auswirkungen auf die Innovationstätigkeit und das ökonomische Wachstum. Im Rahmen eines endogenen Wachstumsmodells wird untersucht, wie Informationsasymmetrien zwischen zwei Agenten, die gemeinsam zur Entwicklung in- 
novativer Kapitalgüter beitragen, auf die Innovationstätigkeit des Forschungs- und Entwicklungssektors und damit auf die Wachstumsrate wirken. Die asymmetrische Informationsverteilung zwischen den Agenten verursacht ein zweiseitiges Moral Hazard Problem, wodurch sich der Arbeitseinsatz beider Agenten signifikant reduziert. Mit Hilfe numerischer Simulationen wird gezeigt, dass der geringere Arbeitseinsatz die Wahrscheinlichkeit, mit der Innovationen erfolgreich umgesetzt werden, um nahezu 25\% senkt. Dies hemmt die Innovationstätigkeit und somit auch die Wachstumsrate der betrachteten Ökonomie substantiell.

Kapitel 3 untersucht, ob Finanzentwicklung dazu beiträgt, Einkommensungleicheit und Armut zu reduzieren. Um diesen Zusammenhang empirisch zu überprüfen, wird eine Reihe unterschiedlicher Indikatoren für Finanzentwicklung verwendet. Die Aufteilung der Länder nach Einkommensniveau erlaubt es, den Unterschieden zwischen Entwicklungsländern und entwickelten Ländern Rechnung zu tragen. Die Ergebnisse zeigen auf, dass Finanzentwicklung Ungleichheit und Armut massgeblich reduziert. Dabei beschränken sich die Resultate nicht nur auf die positive Rolle gut entwickelter Kreditmärkte, sondern weisen insbesondere auch auf die Bedeutung von Aktienmärkten hin.

Kapitel 4 widmet sich den Bestimmungsfaktoren von Finanzentwicklung, mit einem gezielten Fokus auf die Wettbewerbsfähigkeit des Bankensektors. Die Resultate zeigen, dass ein effizienter Aktienmarkt dem Bankensektor zu mehr Wettbewerbsfähigkeit verhilft. Ein effizientes Kostenmanagement nützt nicht nur der Steigerung der Performance der einzelnen Bank in der kurzen Frist, sondern erhöht auch die Wettbewerbsfähigkeit des gesamten Sektors. Die Resultate implizieren, dass eine hohe Marktkonzentration die Wettbewerbsfähigkeit des Bankensektors negativ beinflusst.

Im letzten Kapitel wird schliesslich untersucht, ob und wie sich die Enthüllung von Menschenrechtsverletzungen durch Firmen auf die Finanz-Performance dieser Unternehmen auswirkt. Auf der Basis einer internationalen Stichprobe für ingesamt vier Länder werden die Renditen von Firmen zum Zeitpunkt der Enthüllung analysiert. Während die Resultate für US und UK Firmen zeigen, dass die Investoren unsoziales Verhalten auf den Aktienmärkten mit deutlich negativen abnormalen Renditen bestrafen, kann dieselbe Evidenz für Deutschland und die Schweiz nicht gefunden werden. 